\title{
Landslides in weakly cemented glaciolacustrine sediments, Morkill River valley, British Columbia
}

\author{
Corey R. Froese and David M. Cruden
}

\begin{abstract}
Slopes in weakly cemented glaciolacustrine sediments in the Morkill River valley in the Canadian Rocky Mountains stand at up to $70^{\circ}$. Based on field and laboratory observations it appears that a contributing factor to instability is the softening of the soils by frost action and the leaching of calcite cement. Field density profiles demonstrated increased density and carbonate content with an increase in depth. Laboratory tests of carbonate content indicated a positive correlation between calcium carbonate and density in the glaciolacustrine sediments. The relationship was strongest in sands, in which leaching and dissolution were important components of softening. In clays, frost action was the dominant component of softening. Freeze-thaw tests showed a $50 \%$ decrease in strength after one cycle of freeze and thaw in the silts and clays.
\end{abstract}

Key words: landslide, cemented, glaciolacustrine sediments, British Columbia.

Résumé : Les pentes dans les sédiments glaciolacustres dans la vallée de la rivière Morkill dans les montagnes Rocheuses canadiennes tiennent jusqu'à des angles de $70^{\circ}$. D'après des observations sur le terrain et en laboratoire, il semble qu'un facteur qui contribue à l'instabilité est le ramollissement des sols par l'action du gel et le lessivage du ciment de calcite. Les profils de densité du terrain ont montré une densité et une teneur en carbonate croissantes avec la profondeur. Des essais de teneur en carbonate en laboratoire ont indiqué une corrélation positive entre le carbonate de calcium et la densité dans les sédiments glaciolacustres. La relation était plus marquée dans les sables dans lesquels le lessivage et la dissolution étaient des composantes importantes du ramollissement. Des essais de gel-dégel ont montré une diminution de $50 \%$ de la résistance après un cycle de gel et dégel dans les silts et les argiles.

Mots clés : glissements de terrain, cimenté, sédiments glaciolacustres, Colombie Britannique.

[Traduit par la Rédaction]

\section{Introduction}

Some operational and construction problems in forestry developments in the Morkill River valley in the Canadian Rockies are associated with surficial landslides in glaciolacustrine sediments. Although landsliding in the valley is neither rapid nor deep, it challenges construction to reduce sediment deposition in salmon-spawning streams from constructed cuts and fills and natural slopes. Concerns of environment and government agencies were a driving force in the initiation of this study of the geotechnical properties, distribution, and landslide mechanisms of the weakly cemented soils.

An initial airphoto inventory of landslides in the area, along with a review of the available geological data, highlighted the possibility of the presence of calcium carbonate as a cementing agent in the soils in the valley. The purpose of this paper is to look at the effects of cementation on soils

Received December 16, 1999. Accepted December 7, 2000.

Published on the NRC Research Press Web site at http://cgj.nrc.ca on August 21, 2001.

C.R. Froese. ${ }^{1}$ AMEC Earth \& Environmental Limited, 481093 Street, Edmonton, AB T6E 5M4, Canada.

D.M. Cruden. Department of Civil and Environmental

Engineering, University of Alberta, Edmonton, AB T6G 2G7, Canada.

${ }^{1}$ Corresponding author (e-mail: corey.froese@amec.com). in the Morkill River valley. Experience with carbonate sediments in British Columbia is reviewed. This is followed by a description of the types of landslides observed in the Morkill River valley. The observed effects of weathering on the calcium carbonate cementation in the field and laboratory are addressed, and the effects of chemical and mechanical weathering on these sediments which contribute to instability of slopes in the area are discussed.

\section{Carbonate sediments in Western Canada}

Ford (1989, Fig. 9.34) illustrated the distribution of carbonate and other soluble rocks in Canada; gypsum, limestone, and dolomite outcrop over approximately 1.25 million square kilometres of Canada. As the rocks described by Ford are soluble, carbonate precipitates may be associated with sediments found in these areas. The areas shown in Fig. 9.34 of Ford include the present study area and the areas studied by Boone and Lutenegger (1997) in eastern Ontario, by Smith and Wass $(1994 a, 1994 b)$ in the Canadian Rockies near Golden, British Columbia, and by Haughton (1978) and Nyland and Miller (1977) in the Columbia Lakes and South Thompson regions of British Columbia.

The British Columbia Ministry of Highways studied geological hazards associated with weakly cemented sediments in the Columbia Lakes and South Thompson and Penticton regions of British Columbia (Haughton 1978; Nyland and Miller 1977). More recently, Geertsema and Schwab (1997, 
$1995 a, 1995 b)$ highlighted the occurrence of calcium carbonate as a cementing agent in the glaciomarine sediments of the west coast of British Columbia near Kitimat and Terrace.

Calcium carbonate has been identified as a cementing agent in the silts of the South Thompson region of British Columbia. Hardy (1950) attributed subsidence in the Kamloops silts to the collapse of the internal soil structure after the dissolution of calcium carbonate bonds in the silt. Quigley's (1976) laboratory study of the glaciolacustrine silt deposits of the Columbia Lake area and the South Thompson and Penticton area identified 7-8\% calcium carbonate. Quigley (p. 16) stated the following: "Small amounts of soluble precipitates or evaporites were found. These are significant in that evaporites occurring at the points of contact between silt grains can have a marked effect on the decrease in stability of the silt structure upon wetting."

Smith and Wass $(1994 a, 1994 b)$ reported the impacts of skid roads and stump uprooting on the properties of calcareous loamy soils at Golden, British Columbia, approximately $350 \mathrm{~km}$ southeast of the Morkill River. Although the studies were primarily concerned with the effects of soil disturbance on planted seedling performance, tests of the carbonate content, soil type, and in situ densities were provided. A sandy silt with some clay and 2-8\% carbonates had bulk densities from $1.07 \mathrm{Mg} / \mathrm{m}^{3}$ within the top $0-10 \mathrm{~cm}$ to $1.81 \mathrm{Mg} / \mathrm{m}^{3}$ at a depth of $60-70 \mathrm{~cm}$.

Studies of the retrogressive flow slides in sensitive glaciomarine sediments in the Kitimat-Terrace region (Geertsema and Schwab 1997, 1995a, 1995b) described silts that consisted of glacially ground quartz, feldspar, illite, and chlorite. These mineralogies were similar to those of the sensitive glaciomarine sediments found in eastern Canada and Scandinavia (Geertsema and Schwab 1997). A detailed study of landslide deposits in the Kitimat-Terrace area looked at the ages of the landslides by carbon dating and the effects of leaching on the calcium carbonate content. Calcium carbonate was found in deep soil deposits, but in surficial deposits of relict landslides low $\mathrm{pH}$ values were indicative of the neutralization of calcium carbonate, originally up to $5 \%$ by volume, by acids produced from decaying organic matter. The pore water in the study areas exhibited very low concentrations of $\mathrm{Na}^{+}, \mathrm{Ca}^{2+}, \mathrm{K}^{+}$, and $\mathrm{Mg}^{2+}$, further indications that the majority of leaching had already occurred (Geertsema and Schwab 1997).

This review of the available geotechnical and geological literature did not identify the presence of calcium carbonate as a cementing agent in the soils in the Morkill River valley. Campbell et al. (1973) highlighted the presence of carbonate bedrock but did not discuss the role of cementation in the soils. Reference to carbonate cementation may be lacking because of the remoteness of the area and the fact that the role of cementation is only recently being addressed in the geotechnical literature.

\section{Physical environment}

The Morkill River is a tributary to the Fraser River at the settlement of Crescent Spur, $50 \mathrm{~km}$ northwest of the town of McBride, British Columbia. This area, in the Park Ranges of the Rocky Mountains (Figs. 1, 2), is characterized by folded and faulted sedimentary and metamorphic rocks underlying subparallel ridges and valleys which predominantly trend northwest (Holland 1964).

The Morkill River basin was enveloped by the Cordilleran Ice Sheet during the Pleistocene (Clague 1989). The most significant glaciation, the Late Wisconsinan glaciation known as the Fraser Glaciation, occurred between 29000 and 14000 BP (Ryder et al. 1991). Extensive glaciolacustrine sediments deposited by the decay of this glaciation cover the Morkill River valley.

Mapping of the glaciolacustrine soils in the Morkill River valley (Froese 1998) concluded that six glacial lakes, termed lakes A-F, were impounded in the Morkill River valley by complex stagnation and downwasting of valley glaciers (Fig. 3). In this study, it is hypothesized that the glaciers and their deposits formed natural dams in the Morkill River and tributary valleys, trapping large volumes of sediment. The sediments in these lakes were eroded from the local bedrock in the Morkill and tributary valleys, with the calcite derived from the rocks of the Lower Miette Group or from calciterich till.

\section{Landslide types and processes in the Morkill River valley}

The field mapping program in the Morkill River valley investigated 21 landslides. The types and processes of landslides in the Morkill silts are outlined in the next section, followed by consideration of the sands. The study boundaries for the landslides considered are shown in Fig. 2. Landslide terminology follows Cruden and Varnes (1996).

\section{Silts in lakes A, B, D, and E}

The field investigation included 10 landslides and 71 road-cut exposures in the silt sediments of lakes A, B, D, and $\mathrm{E}$. These soils consist of rhythmically bedded silt, fine sand, and clayey silt. The lateral and vertical distribution of the sediments is presented in Fig. 3. Landslides are initiated by earth slides of the upper $0.3-0.5 \mathrm{~m}$ of root mat and soil, followed by continuing retrogression of the rupture surface. The subsequent landslides are composite slides and flows of the silty soils.

Visual observations and slope measurements in the field mapping program (Froese 1998) showed natural slope angles adjacent to landslides and in road-cut exposures in lakes $\mathrm{A}$, $\mathrm{B}, \mathrm{D}$, and $\mathrm{E}$ ranged from $31^{\circ}$ to $60^{\circ}$. In the landslides investigated, the slope of the surface of rupture in the silty soils ranged from $35^{\circ}$ to $60^{\circ}$. The variation in the rupture surface orientation is postulated to be a function of the duration of exposure and degree of weathering. These in turn would lead to reduction of soil strength by softening, dissolution and leaching of cementation, increased groundwater seepage forces, and reduction of negative pore pressures.

Earth slides in the glaciolacustrine silts of the Morkill River valley have rupture surfaces ranging from 1 to $4 \mathrm{~m}$ in depth and 12 to $150 \mathrm{~m}$ in width. Thin layers of displaced material from retrogressive landslides now cover rupture surfaces. Based on field observations, it appears that the earth slides in the Morkill River valley silts develop seasonally after prolonged exposure to the elements subsequent to the removal of the insulating root mat. Based on the results of the 
Fig. 1. Location plan of the Morkill River study area.

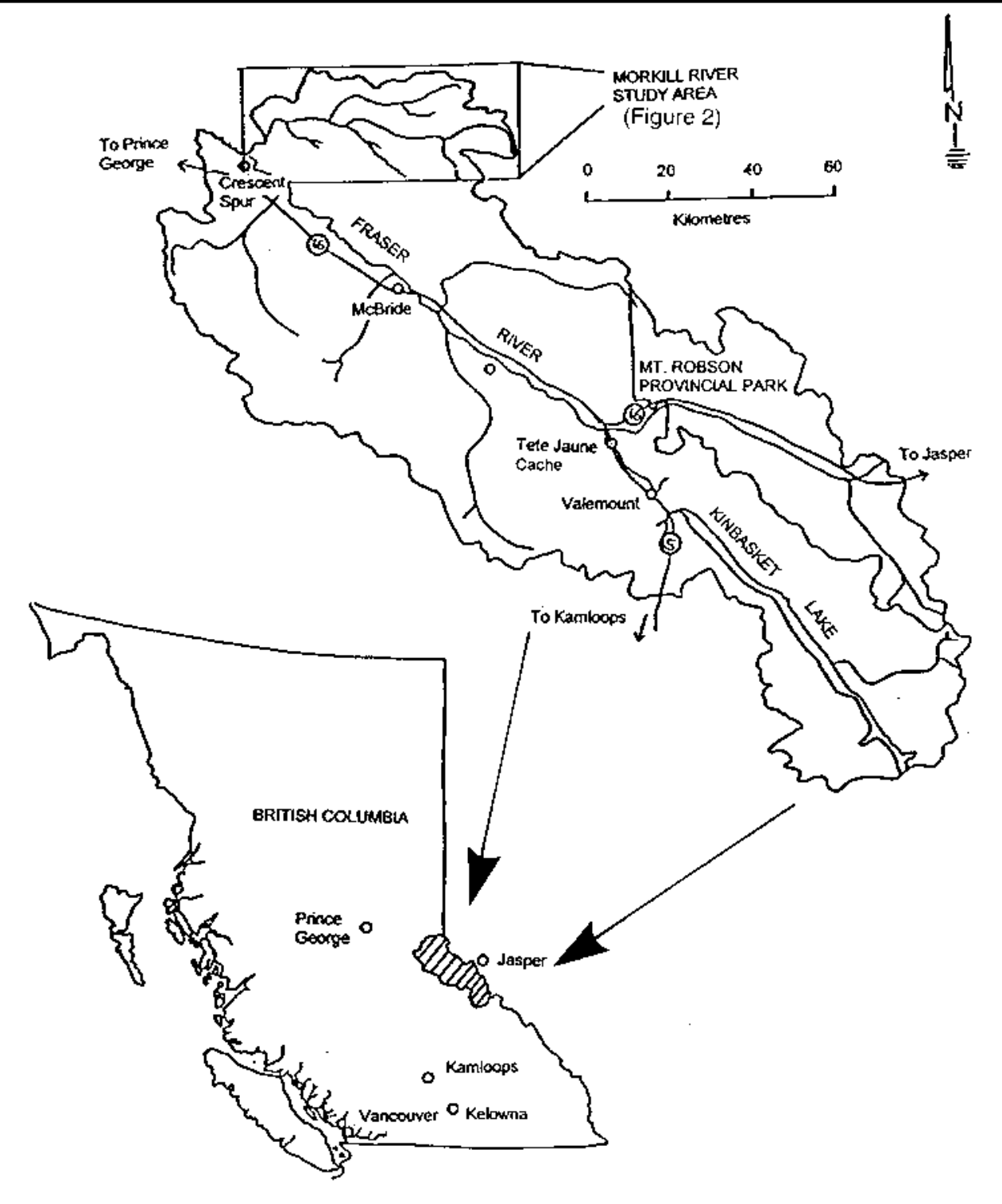

field and laboratory programs, it appears that there is a relationship between the gradual breakdown of the soils due to frost action and the seasonal sliding.

The mechanics of earthflows in the Morkill River valley may follow the description of Cruden and Varnes (1996, p. 66): "Seasonal thaw layers, or active layers, up to a metre or so in thickness may contain water originally drawn to the freezing front where it formed segregated ice. Melting of this ice may generate artesian porewater pressures that greatly reduce the resistance of the active layer to movement."

The silts in the Morkill River valley appear to be extremely sensitive to cycles of freezing and thawing which may accelerate the breakdown of the surficial soil layers thus promoting the infiltration of water. This in turn may lead to a reduction in negative pore pressures and increased leaching of cementing agents in the soil. The upper layer of soil may be at limiting equilibrium, held together by the root mat at the surface. Once the root mat is disturbed, the upper soil and vegetation layer can be expected to slide where slope angles exceed $30^{\circ}$. An example of an earth slide in the silts is shown in Fig. 4.

The exposed slopes in the Morkill River valley appear to be subject to flow failures in the spring, possibly due to the increase in pore pressures and increase in leaching due to increased infiltration from snowmelt. Frost heave has a significant effect on the highly frost susceptible silty soils (Froese 1998). The exposed soils are also susceptible to flow during the spring once the shear strength of the soils has been reduced sufficiently.

The field investigation found layering developed parallel to the slope in the profiles in lakes A, B, D, and E. This layering was indicative of expansion and contraction of the soil matrix due to ice lens formation and frost heave. The melting of these ice lenses leads to excess pore pressures and a decrease in shear strength. 
Fig. 2. Location of study area boundaries and field density locations in the Morkill River valley.

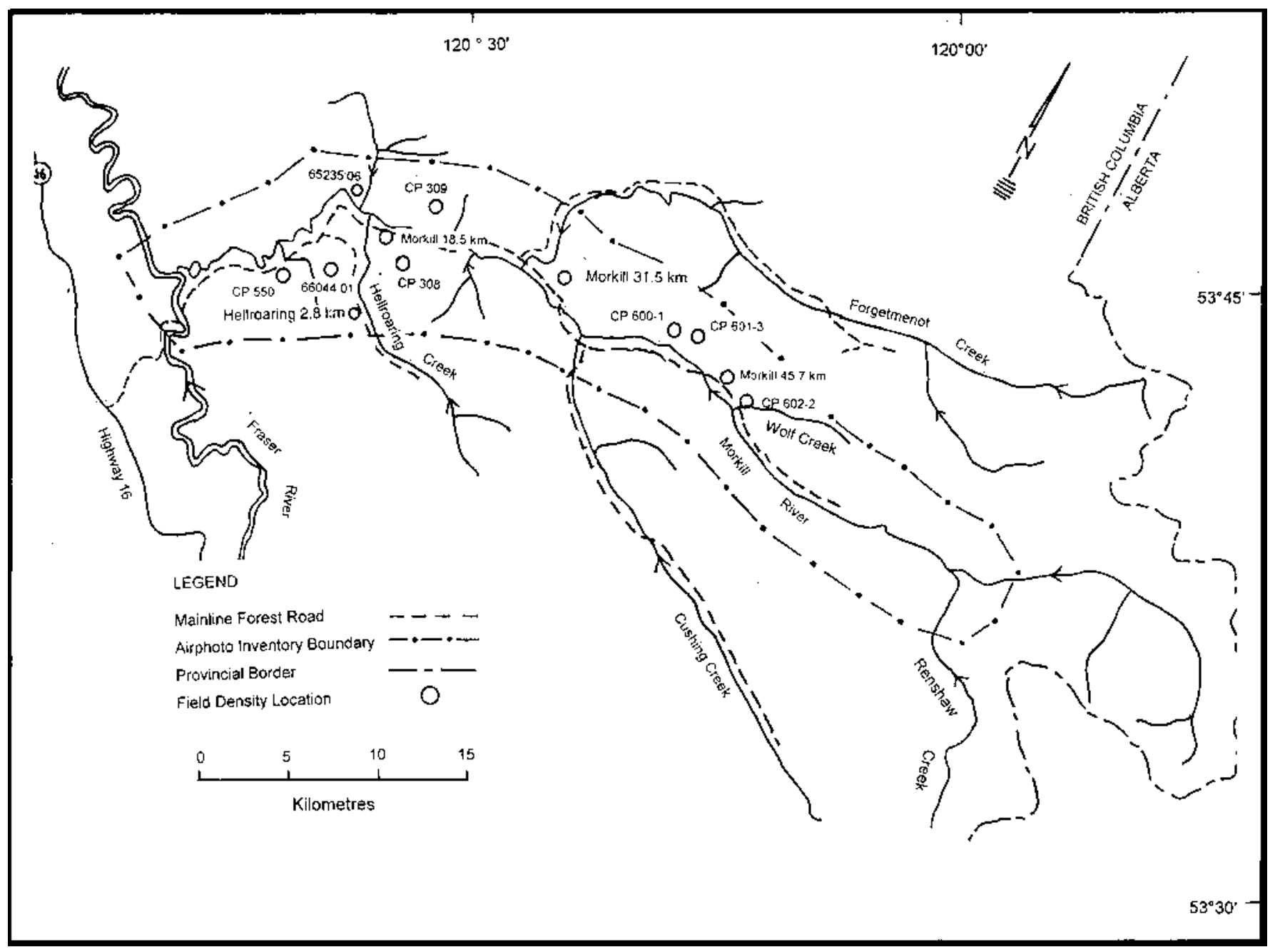

Evidence of successive flow events was noted in the Morkill River valley. The landslide in Fig. 4 appears to have initiated as an earth slide, followed by earthflows in subsequent years.

Lobate features, evidence of seasonal flow due to frost creep, indicate seasonal flow of the surficial soils (Fig. 4). Figure 5 shows the metre or less effective depth of seasonal flow.

Flows from the landslide shown in Fig. 5 and two adjacent landslides have been channeled into a gully and directed onto a flat plain adjacent to the Morkill Forest Service Road (FSR) at kilometre 13. The accumulated soil mass extends $700 \mathrm{~m}$ and is approximately $200 \mathrm{~m}$ wide and over $1.2 \mathrm{~m}$ deep. Test pits excavated into the displaced mass found evidence of organic debris (leaves) separating layers of soil $0.2-0.3 \mathrm{~m}$ thick, indicating that the material has been deposited by several events in different years.

\section{Sands in lake C}

Eleven landslides and 28 soil exposures were examined in the sands of lake C. Landslides in the sandy soils of lake $\mathrm{C}$ consist of shallow, translational earth slides. Natural slope angles adjacent to the slides ranged from $35^{\circ}$ to $44^{\circ}$, with rupture surfaces in the landslides ranging from $37^{\circ}$ to $70^{\circ}$.
The rupture surface at $70^{\circ}$, in a landslide (Fig. 6) that had occurred in late spring of 1997, had not then been exposed to frost or chemical weathering.

The relative contribution of thaw weakening and frost heave is expected to differ from sands to silts. As the freezing front progresses in the sandy soils, there is a downward expulsion of water below the freezing front, thus minimizing the extent of ice lens formation. In silts, varves would be expected to retard the downward flow, and water either freezes at these layers and expands or is diverted along the lower permeability layers. Both processes enhance the loss of shear strength.

Based on the field and laboratory observations, it is assumed that the main factors contributing to instability in the sand soils are dissolution and leaching of calcite and the impacts of increased flow in the unsaturated zone. Both factors lead to a loss of apparent cohesion that may be contributed to by both the impacts of the reduction of negative pore pressures and the dissolution and leaching of cementing agents. The higher permeability sand facilitates water flow and allows it to wash calcite out of the soil matrix more readily. Figure 6 shows a typical earth slide in the sandy soil of lake C. The rupture surfaces in landslides in these sediments typically ranged in depth from 1.0 to $1.5 \mathrm{~m}$. The 
Fig. 3. Schematic cross section showing levels of glacial lake sediments in the Morkill River valley. Locations of tributary creeks shown in Fig. 2.

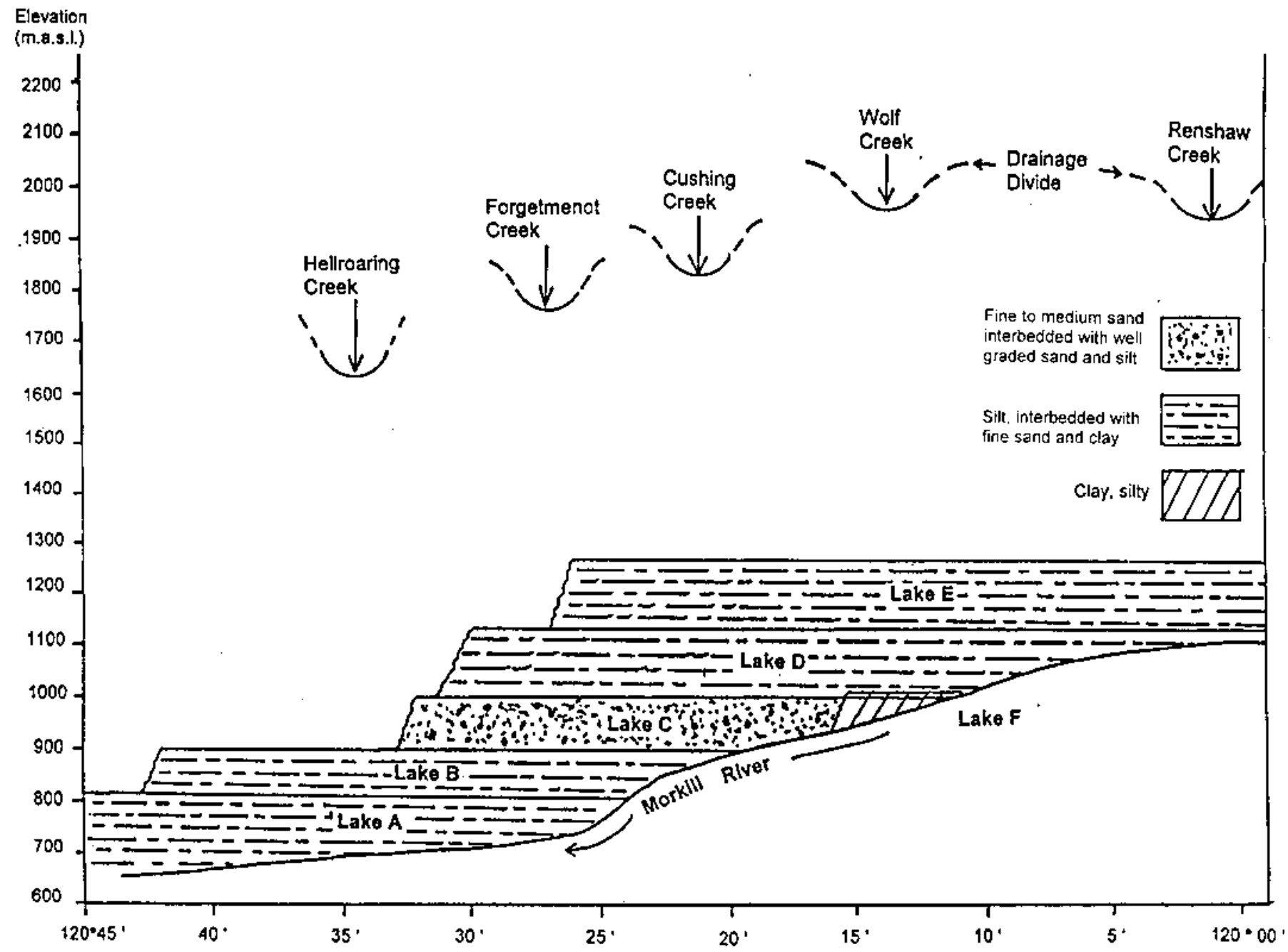

landslide shown in Fig. 6 was assisted by the removal of toe material during road construction and subsequent excavation during seasonal ditch cleaning.

\section{Performance of slopes}

A total of 102 road-cut exposures were visited in the sandy and silty sediments of Morkill River valley. Histograms showing the distribution of slope angles in these sediments are shown in Figs. 7 and 8. Each bar in the histogram has been divided into two sections: slopes that were performing acceptably, showing minimal erosion or instability, and slopes that were not performing acceptably. It is apparent that cuts with slope angles greater than $30^{\circ}$ in the silty and sandy glaciolacustrine sediments have a higher probability of eroding than those with angles less than $30^{\circ}$. Thirty degrees may be a threshold slope angle above which unacceptable performance may occur.

For cohesionless sandy soils, drained friction angles of $30-39^{\circ}$ are typical (Lambe and Whitman 1969, Table 11.2), and therefore the soils are considered to be active in a normal fashion. There is expected to be some variation in this slope-angle threshold based on initial calcium carbonate content, duration of exposure, and degree of weathering. The longer the period of time for which the soils are exposed to surface water and frost action, the deeper the degradation of the soil by weathering and the lower the slope-angle threshold.

In the silty soils, 44 of the slopes were found to be standing above the threshold slope angle of $30^{\circ}$, of which 38 of these were performing acceptably. Some slopes performed acceptably at angles over $30^{\circ}$ because significant amounts of calcite remained in the soil structure to hold the slope above its friction angle. The observed field performance may reflect the lower permeability of the silts, when compared to sands, which in turn impedes groundwater migration. This reduces negative pore pressures and the rate of dissolution and leaching of calcite in the soil matrix. This may explain the observed delay between the time of first exposure and the time of failure.

There were six road-cut exposures of clay in lake F, located between kilometre 47 and kilometre 50 of the Morkill Forest Road. Slope instability consisted of the gradual softening and erosion of the exposed soil due to frost action. Field observations in a road cut at the eastern edge of Cutting Permit (CP) 602 indicated distinct layering forming parallel to the slope surface due to frost heaving. The soils at the surface are blocky and disaggregated due to the frost 
Fig. 4. Slide 66044:01 (see Fig. 2 for location). Photograph and overlay showing lobate flow features in large gully incorporating a large composite earth slide - earthflow.
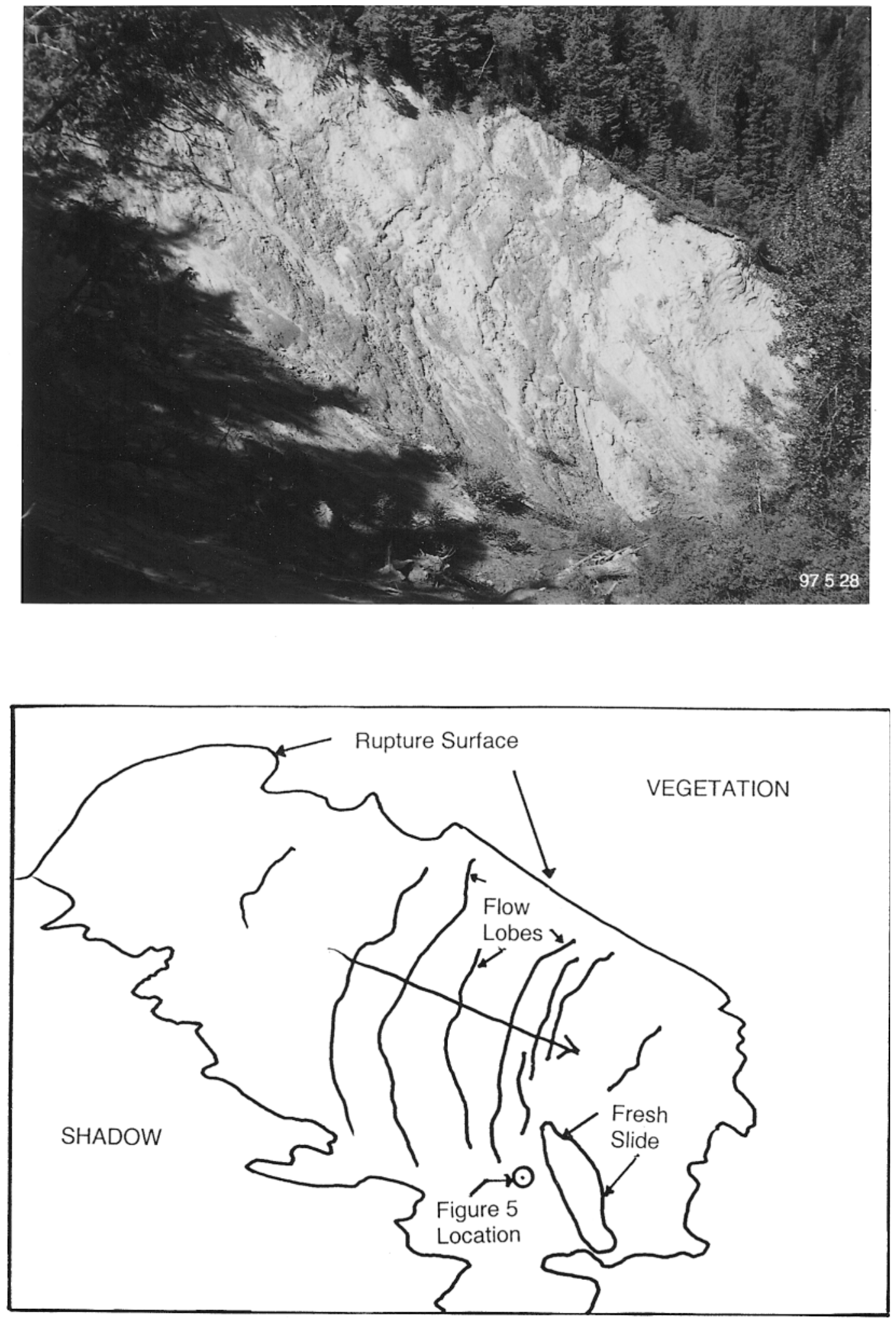

\section{Soil properties}

action. The blocks indicate reticulate ice formation during freezing; water migrates to the edges of soil peds and forms ice, thus separating the soil peds upon expansion of the ice.
The landslide and slope inventories demonstrated that slopes in the Morkill River valley were relatively steep, indicating the possibility of cementation. Natural slopes up to 
Fig. 5. Slide 66044:01 (see Fig. 2 for location). Approximate depth of rupture surface for slide shown in Fig. 4. One metre long shovel for scale.

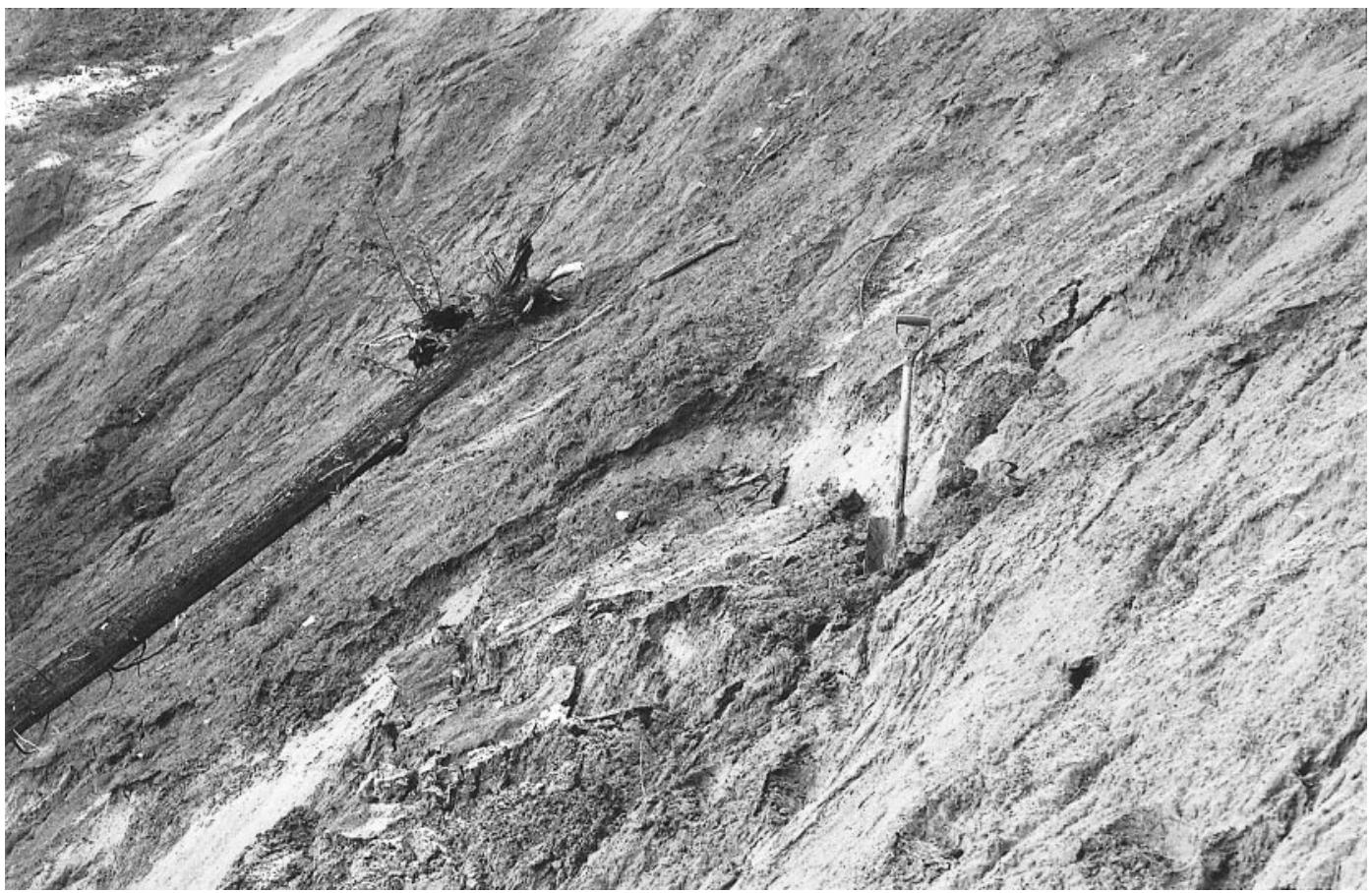

Fig. 6. Morkill $31.5 \mathrm{~km}$ (see Fig. 2 for location). Earth slide in sandy soil below an abandoned cutting permit access road.

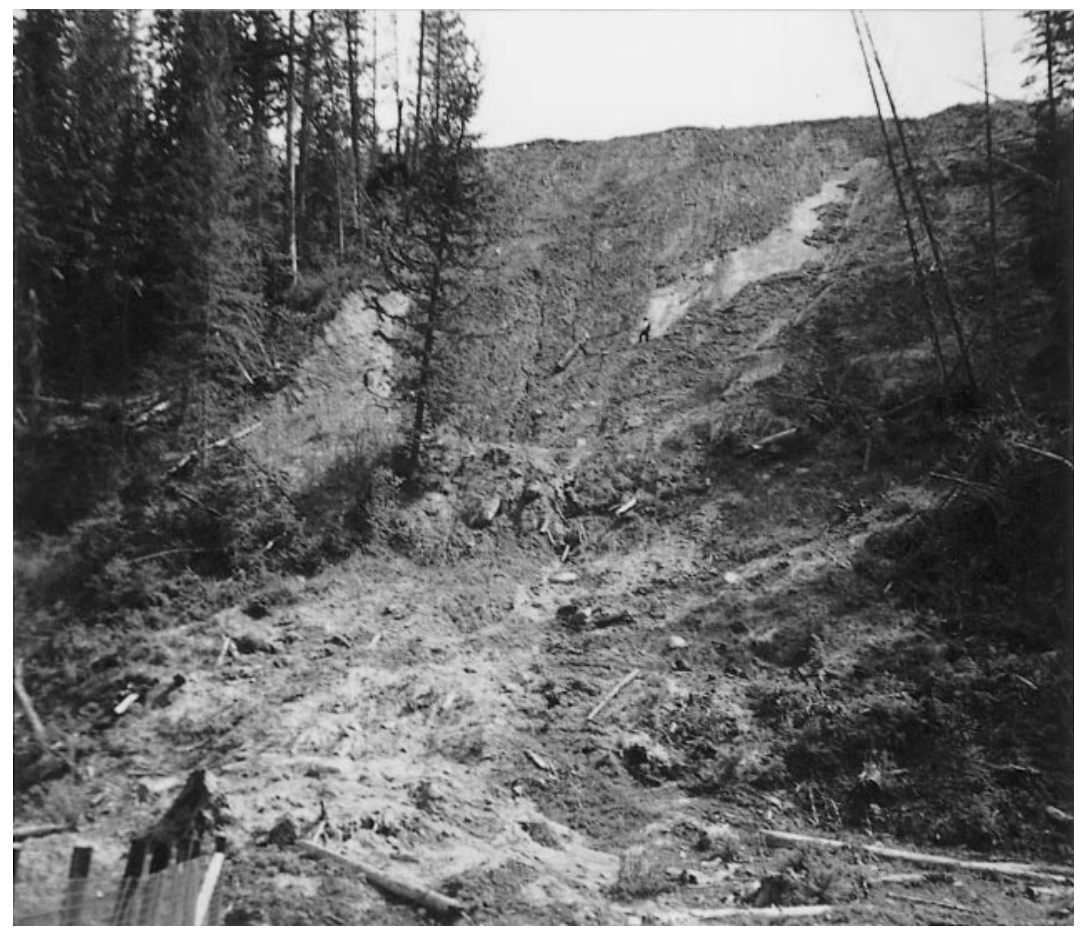

$70^{\circ}$ were noted in silty soils. The limestone in the area led to the assumption that the most likely form of cement in the valley was calcite derived from carbonate bedrock.

Field observations suggest an increase in in situ density with a corresponding increase in carbonate content in the road-cut exposures and landslides. To quantify this relation, in situ testing was undertaken at selected field sites to quan- tify the relative change in density with depth of the glaciolacustrine sediments and also the corresponding change in carbonate content (Fig. 9). The field estimation of carbonate content used a relative scale that was calibrated in the laboratory using samples taken from the density testing program. The soils in the Morkill River valley were classified as weakly to moderately calcareous based on the criteria 
Fig. 7. Slope-angle frequencies in silty soils.

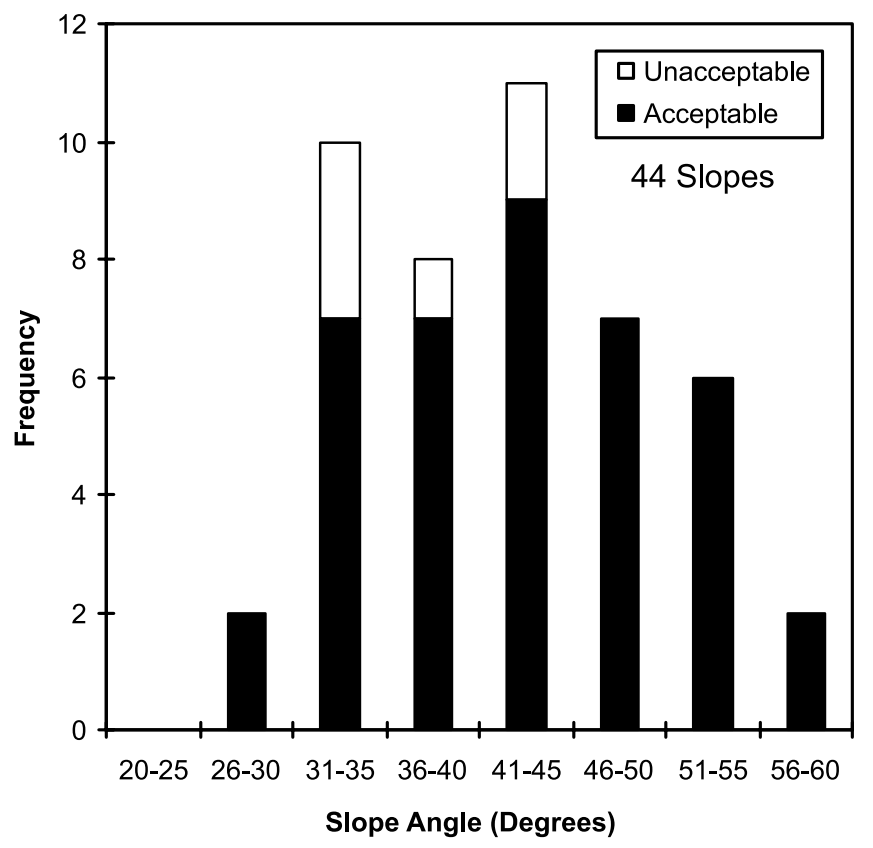

outlined in Agriculture Canada (1974). The in situ density tests yielded densities in the undisturbed silty sediments of up to $2.05 \mathrm{Mg} / \mathrm{m}^{3}$, with corresponding minimum void ratios of 0.36 .

It is suggested that, in addition to the well-documented impacts of the loss of matrix suction and root strength on shallow slope failures, the effects of freezing, leaching, and weathering processes may be important contributing factors to slope performance. The field and laboratory observations suggest that the relative input of the weathering impacts varies with grain size.

\section{Carbonate analyses}

The effects of leaching were investigated during the field and laboratory investigations by addressing the correlation of carbonate content and in situ bulk density. A modified vacuum distillation and titration procedure (Froese 1998) was used to determine the carbonate contents of samples taken during density profiling of the glaciolacustrine soils in the Morkill River valley. Carbonate contents of 5.2-11.1\% were obtained from unweathered samples.

Figure 10 shows the carbonate content versus in situ density plots for selected sites in the Morkill River valley. The plots show that there is a positive correlation for the sites in the silt-size sediments and a slightly steeper trend in the sandier material. The clays did not appear to exhibit any relation between calcium carbonate and density. As there is much scatter in the data, the lines show general trends, not precise relationships. The steeper gradient of the trend for the sands may represent abrupt drops in carbonate content due to enhanced leaching in the higher permeability materials. In contrast, the lower permeability of the finer grained soils does not favour removal of calcite by leaching.

A scanning electron microscope (SEM) was used to observe the structure of the glaciolacustrine sediments and the location of the carbonates in relation to the soil matrix (Fig. 11). The SEM photographs did not show any carbonate
Fig. 8. Slope-angle frequencies in sandy soils.

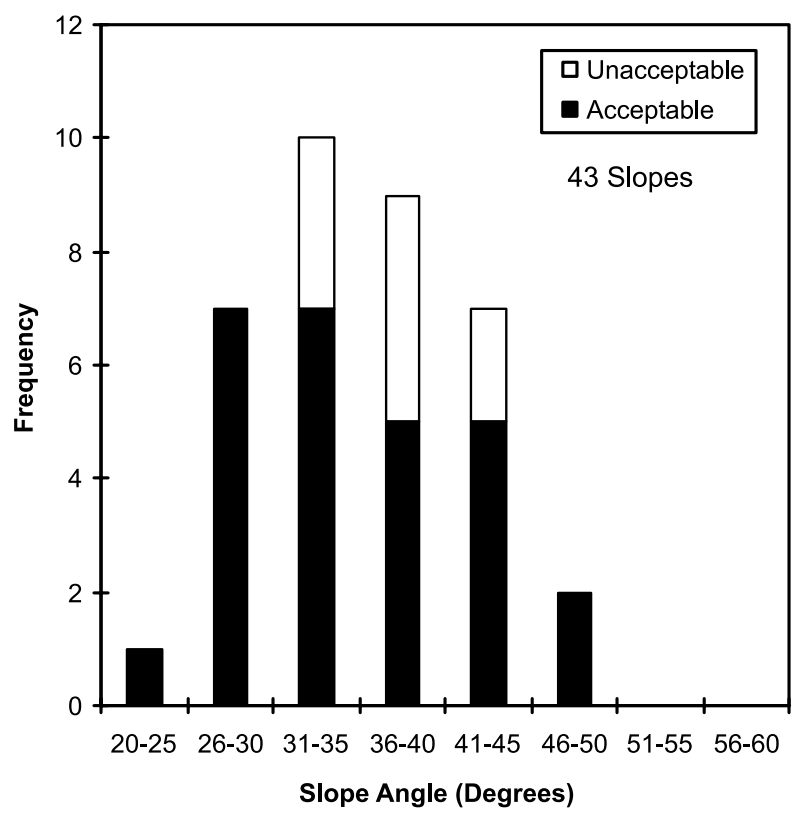

grains. Electron-diffraction analyses of soil grains indicated trace amounts of calcite in the soil matrix. These observations, with the results of the carbonate content determination and the low void ratios, support the view that the carbonates are located in the soil matrix as cement. Calcite present as cement increases the density and strength of the sediment while decreasing its porosity.

\section{Frost susceptibility}

The effects of mechanical weathering by frost action were also addressed in the laboratory program. Frost susceptibility of the glaciolacustrine sediments was assessed using both the index properties of the soils and laboratory strength testing. The U.S. Army Corps of Engineers (1965) classification criteria and the Davila et al. (1993) correlations for segregation potential indicate the soils tested have a moderate to very high susceptibility to frost action and a low susceptibility to frost heave.

The laboratory testing for the effects of frost action on the soils consisted of unconfined compression tests conducted on samples from CP 601 and CP 602 (Froese 1998) which had been subjected to $0,1,2,5$, and 10 cycles of onedimensional freeze and thaw (Fig. 12). Samples exhibited a $50 \%$ decrease in strength after one cycle of freeze and thaw. Visual observations of the samples tested showed that the structure of the sandier sample, CP 601, appeared well bonded after 10 cycles of freeze and thaw, whereas the structure of CP 602 , a sample with $43 \%$ clay size fraction, exhibited stratified ice formation and segregation after 10 cycles of freeze and thaw.

To address the effects of exposure on the silty soils, we utilized the results of the freeze-thaw tests which indicated that values of cohesion of 60 and $35 \mathrm{kPa}$ were available in the silty and silty clay soils, respectively, after one cycle of freeze and thaw (Fig. 12). To evaluate the effects of freeze and thaw on the stability of slopes in the fine-grained sediments of the Morkill River valley, an infinite slope analysis was undertaken. The analysis followed Duncan (1996, 
Fig. 9. Typical density profiles for sites in the Morkill River valley in sand, silt, and clay. Sample locations shown in Fig. 2, and soils classified according to the Unified Soil Classification System.
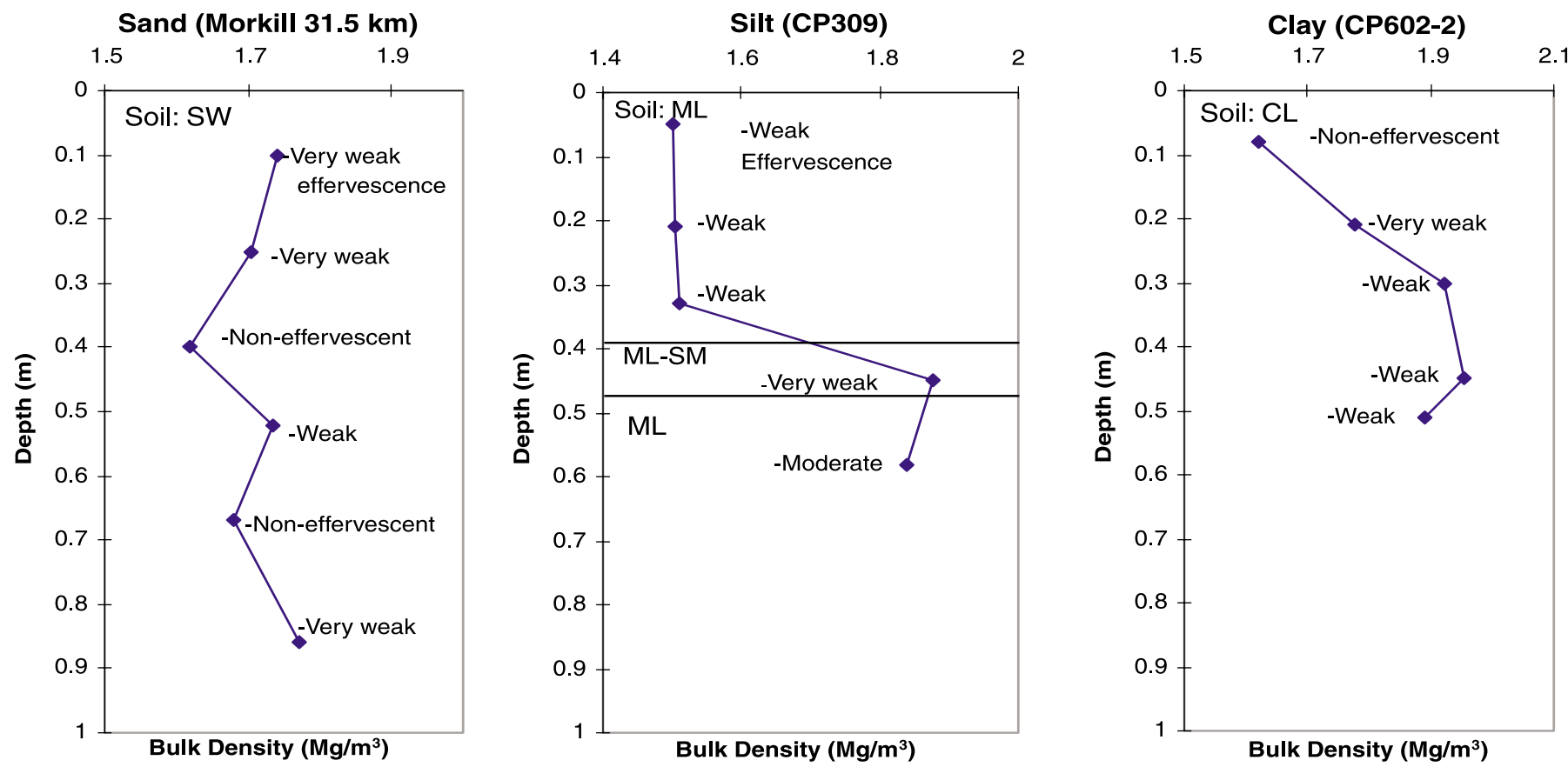

Fig. 10. Relationships between calcium carbonate content and density for typical profiles in the Morkill River valley.

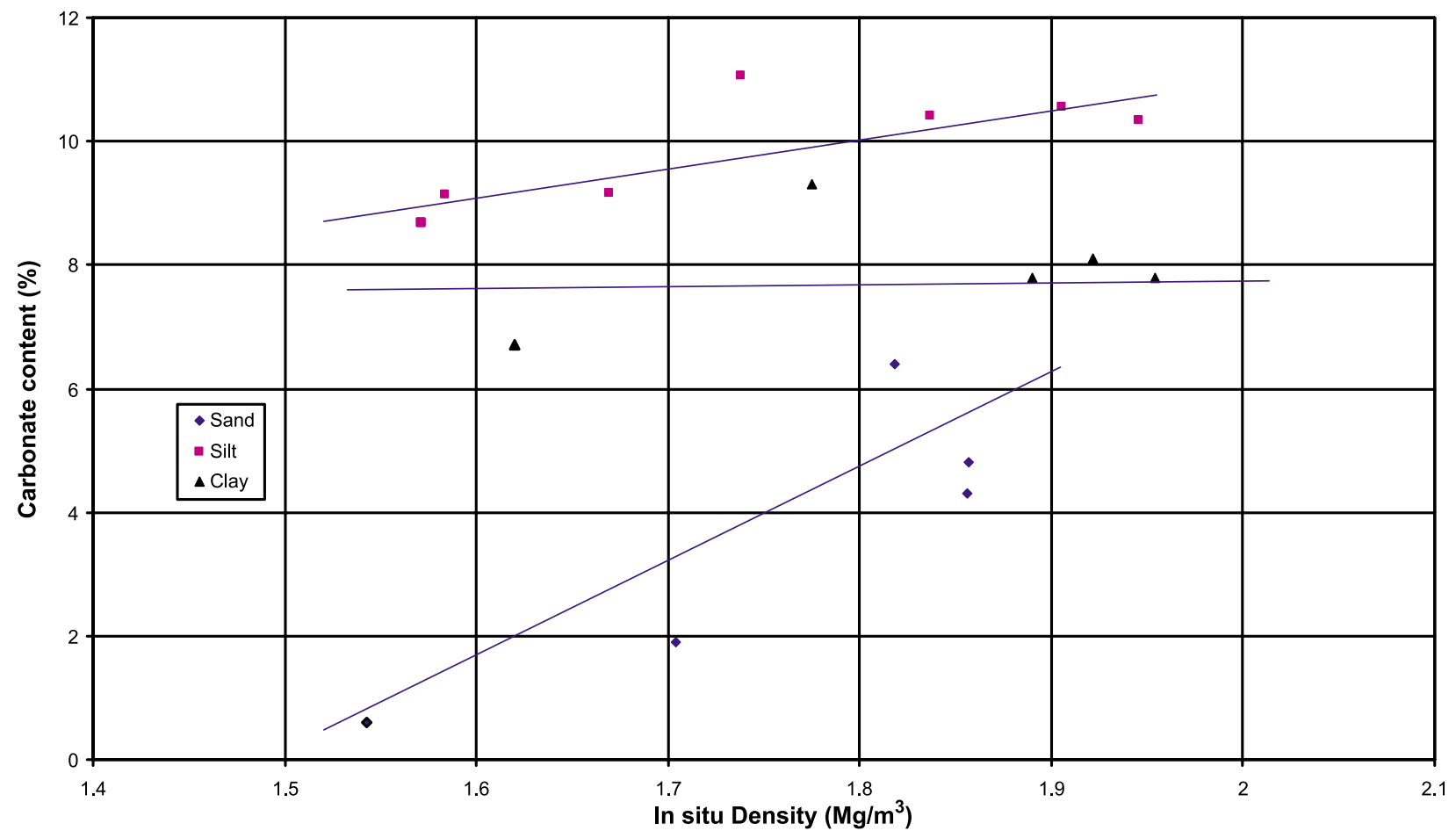

p. 351) and assumed a layer with a thickness of $1 \mathrm{~m}$ and a friction angle of $30^{\circ}$. Due to the enhanced permeability after a cycle of freeze-thaw, pore pressures are assumed to be dissipated and the fully drained condition was modeled.

The infinite slope analysis demonstrates that values of cohesion of less than $10 \mathrm{kPa}$ are required to maintain a slope of $60^{\circ}$ at a factor of safety of 1.0 under short-term condi- tions. As this value is less than the values of cohesion available after one cycle of freeze and thaw, it is considered that the slopes in the silty and silty clay soils require several cycles of freeze and thaw besides the impacts of near-surface seepage gradients and the reduction of negative pore pressures to reduce the soil shear strength to that at limiting equilibrium. 
Fig. 11. Sample 601. Scanning electron microscope image perpendicular to bedding. Magnification 250x.

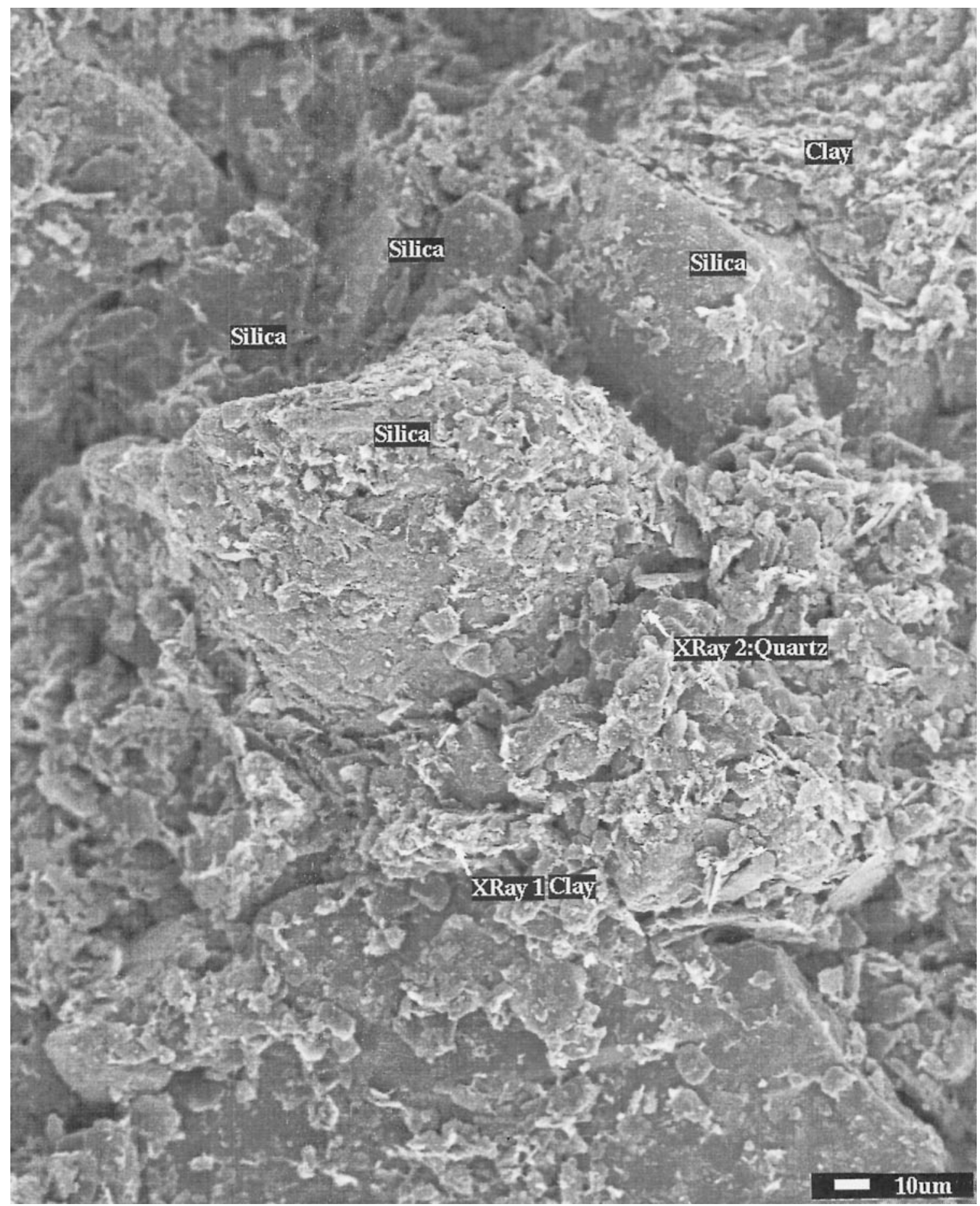

\section{Conclusions}

A contributing mechanism for instability in the stiff Morkill River glaciolacustrine sediments is the process of softening as a result of mechanical and chemical weathering. Based on field and laboratory observations, the processes of frost action and leaching appear to have differing effects on the soils depending on their grain size.

In the sandy soils of lake $\mathrm{C}$, dissolution and leaching of calcite may be enhanced by the relatively high permeability of the soil. As seen in the plot of carbonate content versus in situ density (Fig. 10) and in the density profiles (Fig. 9), there is a relatively steep increase with depth in the carbonate content and density measured in the field in the sandy sediments. This is further substantiated by the observations of landslides in the field. The largest landslides associated with road construction in the Morkill River valley were associated with the sandy glaciolacustrine sediments. Landslides in these soils are predominantly classed as shallow 
Fig. 12. Strength change in unconfined compression test samples subjected to cycles of freeze and thaw. $e$, void ratio.

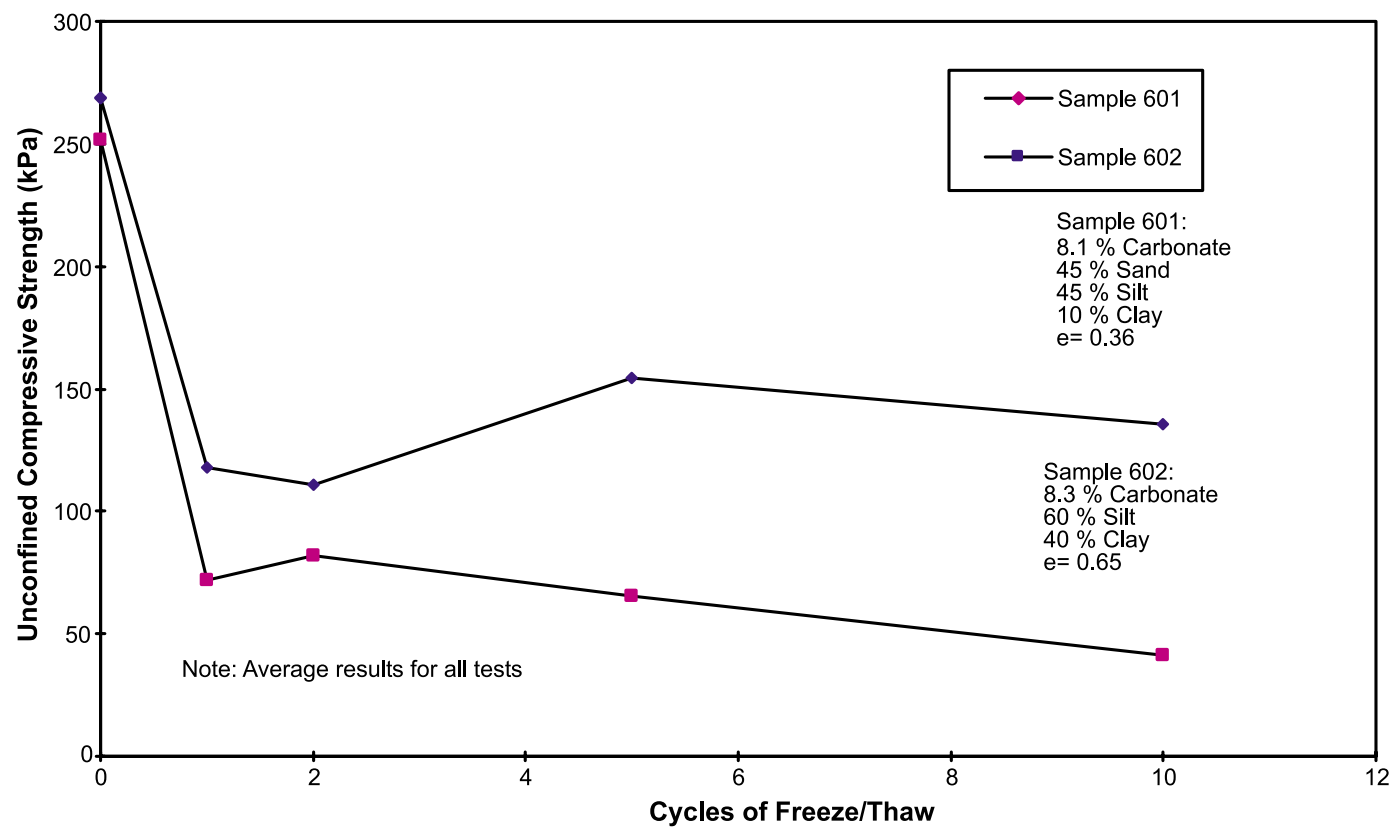

earth slides. These slides are typically $1-1.5 \mathrm{~m}$ thick and 20-75 m wide.

In the silty soils of lakes $\mathrm{A}, \mathrm{B}, \mathrm{D}$, and $\mathrm{E}$, we consider that frost action is the initial dominating weathering process, followed by dissolution and leaching. Once the calcite bonds have been broken due to the $9 \%$ volume expansion upon freezing, the calcite is more readily leached out of the soil structure. The loss of strength noted in the laboratory freeze-thaw testing (Fig. 12) and in the profiles taken in the field indicates that there is a significant effect of frost action followed by slower removal of the calcite for the silty soils when compared to the sandier soils. Landslides in these soils consisted predominantly of shallow composite earth slide earthflow events. It is postulated that slides, incorporating the root mat and upper $0.3 \mathrm{~m}$ of soil, initiate the landslides, followed by erosion of the exposed slope face in the spring. Prolonged exposure is required to lower the values of cohesion in the soils to a point at which limiting equilibrium is achieved.

In the clayey soils of lake F, landslides were not noted in the limited number of exposures investigated. The soil profile for clay shown in Fig. 9 indicated a very gradual increase in density and carbonate content with an increase in depth, and Fig. 10 shows a relatively flat plot of carbonate content versus density (Fig. 10). In these soils, the clay minerals are considered to be the dominant cementing agent, and the low permeability of the material does not favour percolation of groundwater and leaching of carbonates. These soils are susceptible to gradual breakdown of the soil structure due to frost action (Fig. 12).

\section{Acknowledgements}

This study was financially supported by the British Columbia Ministry of Forests, Prince George Forest Region and Robson Valley Forest District, under the direction of Dr. Brent Ward (now with Simon Fraser University) and
Mr. Carl Erickson. Access to laboratory facilities during the field program was made possible by Drs. Max Blouw and Joselito Arocena of the University of Northern British Columbia and by Mr. Barry Tessmer of AGRA Earth \& Environmental Limited.

\section{References}

Agriculture Canada. 1974. The system of soil classification for Canada. Canada Department of Agriculture, Publication 1455.

Boone, S.J., and Lutenegger, A.J. 1997. Carbonates and cementation of glacially derived cohesive soils in New York State and southern Ontario. Canadian Geotechnical Journal, 34: 534-550.

Campbell, R.B., Mountjoy, E.W., and Young, F.G. 1973. Geology of McBride map-area, British Columbia. Geological Survey of Canada, Paper 72-35.

Clague, J.J. 1989. The Cordilleran Ice Sheet. In Quaternary geology of Canada and Greenland. Edited by R.J. Fulton. Geological Survey of Canada, Geology of Canada, No. 1, pp. 15-96.

Cruden, D.M., and Varnes, D.J. 1996. Landslide types and processes. In Landslides: Investigation and Mitigation. Edited by A.K. Turner and R.L. Schuster. Transportation Research Board, Special Report 247, pp. 36-75.

Davila, R.S., Sego, D.C., and Robertson, P.K. 1993. Surface area criteria applied to segregation potential. In Proceedings of the 46th Canadian Geotechnical Conference, pp. 333-342.

Duncan, J.M. 1996. Slope stability analysis. In Landslides: Investigation and Mitigation. Edited by A.K. Turner and R.L. Schuster. Transportation Research Board, Special Report 247, pp. 337371.

Ford, D.C. 1989. Solution processes. In Quaternary geology of Canada and Greenland. Edited by R.J. Fulton. Geological Survey of Canada, Geology of Canada, No. 1, pp. 617-618.

Froese, C.R. 1998. Landslides in the Morkill River Valley, British Columbia. M.Sc. thesis, Department of Civil and Environmental Engineering, University of Alberta, Edmonton, Alta.

Geertsema, M., and Schwab, J.W. 1997. Retrogressive flowslides in the Terrace-Kitimat area, British Columbia: from early post- 
deglaciation to present and implications for future studies. In Proceedings of the 11th Vancouver Geotechnical Society Symposium, Edited by S. Cullum-Kenyon. Forestry Geotechnique and Resource Engineering. Bitech Publishers, Vancouver, B.C. pp. 115-133.

Geertsema, M., and Schwab, J.W. 1995a. The Mink Creek earthflow, Terrace, British Columbia. In Proceedings of the 48th Canadian Geotechnical Conference. pp. 625-633.

Geertsema, M., and Schwab, J.W. 1995b. The Mink Creek earthflow. B.C. Ministry of Forests, Extension Note 4.

Hardy, R.M. 1950. Construction problems in silty soils. Engineering Journal, 33: 775-779.

Haughton, D.R. 1978. Geological hazards and geology of the South Columbia River valley, British Columbia. Geotechnical and Materials Branch, British Columbia Ministry of Highways and Public Works, Victoria, B.C.

Holland, S.S. 1964. Landforms of British Columbia, a physiographic outline. British Columbia Department of Mines and Petroleum Resources, Bulletin 48.

Lambe, T.W., and Whitman, R.V. 1969. Soil mechanics. Wiley, New York.
Nyland, D., and Miller, G.E. 1977. Geologic hazards and urban development of silt deposits in the Penticton area. Geotechnical and Materials Branch, British Columbia Ministry of Highways and Public Works, Victoria, B.C.

Quigley, R.M. 1976. Mineralogy, chemistry and structure, Penticton and South Thompson silt deposits. Report for British Columbia Ministry of Highways and Public Works, Victoria, B.C.

Ryder, J.M., Fulton, R.J., and Clague, J.J. 1991. The Cordilleran ice sheet and the glacial geomorphology of southern and central British Columbia. Géographie physique et Quaternaire, 45: 365-377.

Smith, R.B., and Wass, E.F. 1994a. Impacts of a stump uprooting operation on properties of a calcareous loamy soil and on planted seedling performance. Canadian Forestry Service, Pacific Forestry Centre, Information Report BC-X-344.

Smith, R.B., and Wass, E.F. 1994b. Impacts of skidroads on properties of a calcareous loamy soil and on planted seedling performance. Canadian Forestry Service, Pacific Forestry Centre, Information Report BC-X-346.

U.S. Army Corps of Engineers. 1965. Soils and geology-pavement design for frost conditions. Department of the Army, Technical Manual TM5-818-2. 